Boston University School of Law

Scholarly Commons at Boston University School of Law

Faculty Scholarship

$12-2002$

Independent External Review of Health Maintenance

Organizations' Medical-Necessity Decisions

Wendy K. Mariner

Follow this and additional works at: https://scholarship.law.bu.edu/faculty_scholarship

Part of the Health Law and Policy Commons 
Lugal Issues in Medicine

\section{INDEPENDENT EXTERNAL REVIEW of Health Maintenance Organizations' Medical- NeCESSity Decisions}

\author{
Wendy K. MARINER, J.D., M.P.H.
}

S TATES may have more freedom to regulate the practices of managed-care organizations than many observers previously believed. In the absence of congressional action on the federal Bipartisan Patient Protection Act, ${ }^{1}$ the primary source of patientprotection legislation remains at the state level. Nevertheless, the federal Employee Retirement Income Security Act (ERISA) of $1974^{2}$ restricts state regulation of health maintenance organizations (HMOs) that serve private employee group health plans. On June 20, 2002, the U.S. Supreme Court, in Rush Prudential $H M O$, Inc. v. Moran, upheld an Illinois state law that requires binding independent external review when an HMO disagrees with the decision of a patient's physician that a treatment is medically necessary. ${ }^{3}$ The $\mathrm{Mo}^{-}$ ran decision clarifies the states' authority, and may allow physicians a larger say in decisions about managed-care coverage.

\section{STATE REGULATION AND ERISA}

Forty-one states and the District of Columbia have laws requiring independent external review of denials of benefits by HMOs, although these laws vary in what types of decisions they apply to, who conducts the review, what rules the reviewers must use, and whether reviewers' decisions are binding (Table 1). Their general purpose is to ensure that decisions about an individual patient's care are made on the basis of sound medical judgment rather than financial or business considerations alone. The Illinois law applies in very narrow circumstances. Section 4-10 of the Illinois Health Maintenance Organization Act requires HMOs licensed in Illinois to submit benefit denials to an independent physician reviewer (unaffiliated with the $\mathrm{HMO}$ and jointly selected by the patient, the patient's physician, and the HMO) "in the event of a dispute between the primary care physician and the [HMO] regarding the medical necessity of a covered service proposed by a primary care physician." "If the independent reviewer decides that the treatment is medically necessary - and if it is a covered service under

From the Health Law Department, Boston University School of Public Health, Boston. the HMO contract - the HMO is required to provide the covered service. ${ }^{4}$

Laws such as this one are typically part of a state's statutes licensing health insurance companies, HMOs, preferred-provider organizations, and Blue Cross and Blue Shield. ${ }^{5}$ States - not the federal government - have historically regulated insurance. ${ }^{6}$ State regulation failed to protect employees from the loss of pensions, however, so Congress enacted ERISA in 1974 to set national standards for employers who voluntarily offered pension plans to their employees. ${ }^{78}$ To achieve national uniformity, Section 514 of ERISA supersedes ("preempts") any state law that "relates" to an ERISA plan. ${ }^{9,10}$ (An ERISA plan is any plan created by a private employer, group of employers, or union, with a few exceptions, to offer pensions, health coverage, or other benefits to employees. ${ }^{11}$ ) More than 125 million Americans obtain health care financed by ERISA plans. ${ }^{12,13}$ The preemption by ERISA limits the application of state licensing statutes and other laws in complicated ways, making it hard to predict whether certain laws protect all the patients in a state. ${ }^{14,15}$

\section{MORAN'S DISPUTE WITH RUSH PRUDENTIAL}

Deborah Moran was a member of Rush Prudential HMO, an HMO licensed under the Illinois act. Her husband's employer sponsored a fully insured ERISA plan that provided memberships in this HMO for employees and their dependents. Moran saw Dr. Arthur LaMarre, her Rush network primary care physician, for pain, numbness, and loss of mobility in her right shoulder in 1996. Conservative measures, such as physiotherapy, that were recommended by Dr. LaMarre did not relieve these symptoms. On her own, Moran saw Dr. Julia Terzis, an out-of-network surgeon in Virginia, who diagnosed brachial plexopathy and the thoracic outlet syndrome, a nerve-compression syndrome, and recommended decompression by removal of the uppermost rib, extensive scalenectomy, and microneurolysis (removal of scar tissue around the injured nerves) of the brachial plexus under microscopical magnification.

Moran asked LaMarre to obtain Rush's approval for Terzis to perform this surgery. Two Rush-affiliated surgeons confirmed the diagnosis of the thoracic outlet syndrome but recommended standard surgery, with less extensive scalenectomy and neurolysis and no microneurolysis. Moran believed Terzis's approach offered a better prognosis, and LaMarre told Rush that Moran would be "best served" by Terzis's surgery. Rush denied approval because Terzis was not a Rush network physician. Moran appealed, and Rush again denied approval, after consulting the literature and its two surgeons, who confirmed that microneurolysis was not necessary. Instead, Rush approved 
Table 1. States with Laws Requiring Independent External Review.

\begin{tabular}{|c|c|c|c|c|c|}
\hline State or District & $\begin{array}{l}\text { INDEPENDENT } \\
\text { REVIEW } \\
\text { REQUIRED }\end{array}$ & $\begin{array}{c}\text { ALL } \\
\text { DeCISIONS* }\end{array}$ & $\begin{array}{c}\text { DeCISIONS ABOUT } \\
\text { MEDICAL } \\
\text { NECESSITY }\end{array}$ & $\begin{array}{c}\text { DECISIONS } \\
\text { ABOUT MEDICAL } \\
\text { NECESSITY AND } \\
\text { EXPERIMENTAL } \\
\text { TREATMENT‡ }\end{array}$ & $\begin{array}{l}\text { BINDING } \\
\text { REVIEW§ }\end{array}$ \\
\hline Alaska & $\mathrm{X}$ & & & $\mathrm{X}$ & $\mathrm{X}$ \\
\hline Arizona & $\mathrm{X}$ & $\mathrm{X}$ & & & $\mathrm{X}$ \\
\hline California & $\mathrm{X}$ & & $\mathrm{X}$ & & $\mathrm{X}$ \\
\hline Colorado & $\mathrm{X}$ & & & $\mathrm{X}$ & $\mathrm{X}$ \\
\hline Connecticut & $\mathrm{X}$ & $\mathrm{X}$ & & & $\mathrm{X}$ \\
\hline Delaware & $\mathrm{X}$ & & $\mathrm{X}$ & & $\mathrm{X}$ \\
\hline District of Columbia & $\mathrm{X}$ & $X$ & & & \\
\hline Florida & $\mathrm{X}$ & $\mathrm{X}$ & & & \\
\hline Georgia & $\mathrm{X}$ & $\mathrm{X}$ & & & $\mathrm{X}$ \\
\hline Hawaii & $\mathrm{X}$ & $\mathrm{X}$ & & & \\
\hline Illinois & $\mathrm{X}$ & & $\mathrm{X}$ & & $\mathrm{X}$ \\
\hline Indiana & $\mathrm{X}$ & & & $\mathrm{X}$ & $\mathrm{X}$ \\
\hline Iowa & $\mathrm{X}$ & & $\mathrm{X}$ & & $\mathrm{X}$ \\
\hline Kansas & $\mathrm{X}$ & & & $\mathrm{X}$ & \\
\hline Kentucky & $\mathrm{X}$ & & & $\mathrm{X}$ & $\mathrm{X}$ \\
\hline Louisiana & $\mathrm{X}$ & & $\mathrm{X}$ & & $\mathrm{X}$ \\
\hline Maine & $\mathrm{X}$ & $\mathrm{X}$ & & & $\mathrm{X}$ \\
\hline Maryland & $\mathrm{X}$ & & $\mathrm{X}$ & & \\
\hline Massachusetts & $\mathrm{X}$ & & $\mathrm{X}$ & & $\mathrm{X}$ \\
\hline Michigan & $\mathrm{X}$ & & $\mathrm{X}$ & & $\mathrm{X}$ \\
\hline Minnesota & $\mathrm{X}$ & & $\mathrm{X}$ & & $\mathrm{X}$ \\
\hline Missouri & $\mathrm{X}$ & $\mathrm{X}$ & & & $\mathrm{X}$ \\
\hline Montana & $\mathrm{X}$ & & $\mathrm{X}$ & & $\mathrm{X}$ \\
\hline New Hampshire & $\mathrm{X}$ & & $\mathrm{X}$ & & $\mathrm{X}$ \\
\hline New Jersey & $\mathrm{X}$ & & $\mathrm{X}$ & & $\mathrm{X}$ \\
\hline New Mexico & $\mathrm{X}$ & $\mathrm{X}$ & & & $\mathrm{X}$ \\
\hline New York & $\mathrm{X}$ & & & $\mathrm{X}$ & $\mathrm{X}$ \\
\hline North Carolina & $\mathrm{X}$ & $\mathrm{X}$ & & & \\
\hline Ohio & $\mathrm{X}$ & & $\mathrm{X}$ & & $\mathrm{X}$ \\
\hline Oklahoma & $\mathrm{X}$ & & $\mathrm{X}$ & & \\
\hline Oregon & $\mathrm{X}$ & & & $\mathrm{X}$ & \\
\hline Pennsylvania & $\mathrm{X}$ & & $\mathrm{X}$ & & $\mathrm{X}$ \\
\hline Rhode Island & $\mathrm{X}$ & & $\mathrm{X}$ & & $\mathrm{X}$ \\
\hline South Carolina & $\mathrm{X}$ & & & $\mathrm{X}$ & $\mathrm{X}$ \\
\hline Tennessee & $\mathrm{X}$ & & & $\mathrm{X}$ & $\mathrm{X}$ \\
\hline Texas & $\mathrm{X}$ & & $\mathrm{X}$ & & $\mathrm{X}$ \\
\hline Utah & $\mathrm{X}$ & & $\mathrm{X}$ & & $\mathrm{X}$ \\
\hline Vermont & $\mathrm{X}$ & & & $\mathrm{X}$ & $\mathrm{X}$ \\
\hline Virginia & $\mathrm{X}$ & $\mathrm{X}$ & & & $\mathrm{X}$ \\
\hline Washington & $\mathrm{X}$ & & $\mathrm{X}$ & & $\mathrm{X}$ \\
\hline West Virginia & $\mathrm{X}$ & & & $\mathrm{X}$ & $\mathrm{X}$ \\
\hline Wisconsin & $\mathrm{X}$ & & & $\mathrm{X}$ & $\mathrm{X}$ \\
\hline Total & 42 & 11 & 19 & 12 & 34 \\
\hline
\end{tabular}

*The state law applies to all coverage decisions made by the health maintenance organization. †The state law applies only to determinations about medical necessity.

$\ddagger$ The state law applies only to determinations about medical necessity or the experimental nature of treatment.

$\$$ The decision resulting from the independent external review is binding on the health maintenance organization. 
standard surgery for the thoracic outlet syndrome, to be performed by a Rush network surgeon.

Moran demanded that Rush submit the dispute for independent external review under section 4-10 of the Illinois Health Maintenance Organization Act, but Rush did not do so. The next month, Moran underwent surgery performed by Terzis, paying the $\$ 94,841.27$ charge herself. She then claimed reimbursement from Rush, which denied the claim after conducting another review with additional physicians.

Finally, Moran filed suit in Illinois state court and won a judgment forcing Rush to submit to independent review. An independent physician reviewer found that the surgery, including microneurolysis, was medically necessary. Moran then asked the state court to require Rush to reimburse her for the cost of the surgery. Rush moved the case to federal court, claiming that it did not have to comply with the independent review because ERISA preempted section 4-10 of the Illinois act. ${ }^{16}$

\section{THE SUPREME COURT DECISION}

The Supreme Court did not decide whether Moran's preferred treatment was in fact medically necessary - a question on which reasonable people might disagree. The question before the Court was whether Rush had to comply with the Illinois law and submit to independent review. The Court held that it did, in a five-to-four opinion written by Justice David Souter, joined by Justices John Paul Stevens, Sandra Day O'Connor, Ruth Bader Ginsburg, and Stephen Breyer. $^{3}$

The Court's decision turned on a technical analysis of ERISA preemption. ERISA does not preempt state laws that regulate insurance. However, state laws that relate to ERISA plans, as the Illinois law did in this case, can be enforced only if they qualify as regulating the "business of insurance," which is a term of art. ${ }^{17,18}$ It does not include everything an insurance company happens to do but, rather, is limited to traditional insurance practices such as accepting and spreading financial risk, underwriting, and making decisions about coverage. ${ }^{19-21}$ The Court has used two tests to determine whether a law regulates insurance. First, under the so-called common-sense test, the law must be directed specifically at the insurance industry and not commerce or contracts in general. ${ }^{20}$ Rush argued that HMOs are not engaged in the business of insurance because they provide medical care. The Court rejected that argument, finding that HMOs also provide insurance by accepting fixed premiums and taking on the financial risk of providing care. Thus, state laws that regulate insurance functions can be applied to HMOs, as to other insurers.

Under the second test, the state law must target one of three key characteristics of insurance: the transfer or spread of a policyholder's risk, the policy rela- tionship between the insured and the insurer, or practices limited to the insurance industry specifically. ${ }^{18,20,22,23}$ The Court found that section 4-10 of the Illinois HMO Act affects the second - the policy relationship between Moran, the insured, and Rush, the insurer - by adding a mandated term to the policy. Moreover, the independent review required by the Illinois law entailed interpreting the insurance policy, which the Court said was "at the 'core' of the business of insurance." 3 The Illinois law also targeted the third characteristic, since HMO policies are insurance policies. Therefore, the Illinois law qualified as insurance regulation and was not preempted by ERISA, so Rush was required to comply with independent external review.

Rush then argued that even if the Illinois law was not preempted by ERISA because it regulates insurance, it conflicted with another ERISA provision and should not be enforced. ERISA section 502(a) grants plan participants the right to sue the ERISA plan to enforce their rights under the plan or to recover the dollar amount of any wrongfully denied plan benefit (i.e., the cost of a medical or diagnostic procedure, but not compensation for personal injuries, such as lost wages or additional medical expenses). ${ }^{24,25}$ Earlier Supreme Court decisions held that participants in an ERISA plan cannot use state law to obtain a remedy for denied benefits that section 502(a) does not provide, such as punitive damages. ${ }^{26-29}$ Rush interpreted these decisions to mean that the states could not require HMOs to use any other method of resolving disputes with participants in an ERISA plan, including state-mandated independent review or arbitration. Uncertainty about whether ERISA forbids any dispute-resolution methods except a lawsuit under section 502 (a) has bedeviled the states, ${ }^{14,30-32}$ prompted federal regulations regarding new internal-review procedures, ${ }^{33}$ and encouraged the pending federal legislation that would require independent review for all ERISA plans. ${ }^{1}$

The majority of the Court rejected Rush's argument, resolving much of the uncertainty. The Court ruled that section 502(a) does not address preemption at all. The fact that section 502(a) provides a remedy for denied benefits does not mean that ERISA automatically preempts a state law. The Court also noted that the Illinois law did not actually give ERISA plan participants an additional remedy. It merely required the HMO to use an additional level of appeal before finally denying benefits. If an HMO refused to submit to independent review, a patient like Moran could bring a lawsuit under section 502(a) to force compliance with independent review. If an HMO refused to pay covered benefits, the patient would still have to bring a lawsuit under ERISA section 502(a) - not state law - to collect payment. Thus, the law was consistent with ERISA and applied to Rush.

2180 • N Engl J Med, Vol. 347, No. 26 • December 26, $2002 \cdot$ www.nejm.org 


\section{IMPLICATIONS OF THE DECISION}

The Moran decision opens the door to more extensive state regulation of HMOs. There is no doubt that states are free to regulate the quality of medical care and medical practice, because medical care itself does not relate to ERISA plans. ${ }^{34-37}$ ERISA plan participants may sue physicians for malpractice because medical judgment is not related to ERISA plans. ${ }^{38-40}$ What the Moran decision clarified is that states are also free to regulate insurance as a way to regulate the practice of medicine and protect the quality of care. This might include imposing professional standards for the quality of care offered by HMOs or requiring coverage of medically necessary care as a mandated benefit. These requirements should increase the role of physicians in determining the quality of care that must be provided as part of an HMO policy.

The decision indicates that the majority of state laws requiring independent review of benefit denials can be enforced against HMOs. Although Illinois's law was narrow - applying only to disputes over medical necessity between an HMO and a physician - the Court's reasoning appears applicable to broader state laws. My analysis of state laws reveals that 19 states, including Illinois, currently limit the requirement of independent external review to disputes about medical necessity (Table 1). An additional 12 states require independent review only for disputes about medical necessity and about whether a treatment is experimental. All these state laws should be enforceable against HMOs.

Ten states and the District of Columbia have independent-review laws that appear also to apply to disputes over the interpretation of the scope of coverage or an insurance contract (Table 1). In 2000, the Fifth Circuit Court of Appeals struck down a Texas law requiring independent external review in cases of disputes over benefit coverage, concluding that it provided an alternative remedy that conflicted with ERISA section 502(a). ${ }^{41}$ In Moran, the Supreme Court rejected the same argument by Rush. Four days later, it unanimously vacated the Fifth Circuit Court's decision and sent it back for further consideration in the light of the ruling in Moran. ${ }^{42}$ Thus, further proceedings may determine whether decisions about coverage that do not depend on medical judgment about medical necessity may be subject to independent review under state law.

Nine states have no law requiring independent external review of HMO benefit denials. The Moran decision may encourage these states to adopt such laws. Surveys show that the public favors independent review of benefit decisions. ${ }^{43}$ The Court appeared to agree, by drawing an analogy between independent review of decisions about medical necessity and the practice of getting another physician's medical opinion. It also hinted that state law might forbid HMOs from writing contracts that reserve for the HMO the sole authority to make decisions about medical necessity.

The Supreme Court has now made clear that state independent-review laws can apply to HMOs that sell their own policies to fully insured ERISA plans. (Fully insured ERISA plans provide health benefits to employees by buying a group health insurance policy from an insurance company or HMO; employees receive whatever benefits the HMO's policy covers.) The question is whether such laws may also apply to HMOs that merely administer self-funded ERISA plans. The Court did not have to decide this question, because Moran's ERISA plan was fully insured.

An estimated 40 percent of all participants in ERISA plans are in self-funded plans. ${ }^{12}$ Self-funded (or "selfinsured") ERISA plans do not buy insurance policies from an HMO. Instead, the ERISA plan itself pays for health care services directly out of plan assets (i.e., employer and employee contributions). Most self-funded ERISA plans hire an HMO, for a fixed fee, to administer the health benefits under the plan and to make decisions about coverage, because the employer has no particular expertise to do so. ${ }^{44}$

The Court's reasoning suggests that states could require all HMOs that make coverage decisions to provide independent external review as a condition of licensure, at least when the decision involves questions of medical judgment. The Court found that making benefit decisions is a core insurance function and that laws regulating how such decisions are made qualify as insurance regulation and are therefore not preempted by ERISA. It also noted that there was "nothing standing in the way" of applying this insurance exception from preemption by ERISA to HMOs that provide only administrative services to a self-funded ERISA plan. ${ }^{3}$ Therefore, states should be able to require HMOs that make final decisions about coverage for ERISA plans to use independent external review (although they could not require ERISA plans themselves to do so).

This interpretation may depend on whether the HMO has the ultimate authority to make final judgments about medical necessity and benefit coverage. Some self-funded ERISA plans give HMOs the discretion to make final, binding decisions about benefits, but others do not. If the ERISA plan does not grant the HMO the discretion to make final decisions, then the HMO's administrative functions might not qualify as the "business of insurance" and therefore would not be subject to state laws regulating insurance. If this interpretation is correct, an HMO could avoid compliance with independent-review laws by refusing to accept ultimate decision-making authority on behalf of a self-funded ERISA plan. Alternatively, a self-funded ERISA plan could retain the right to approve any decision made by an HMO, so that the HMO would 
not have to comply with a requirement for independent review. In effect, the terms of the administrativeservices contract between the ERISA plan and the HMO could determine whether or not a state insurance law applied to the HMO. The contract terms might not change how coverage decisions are made in practice, but they would be likely to control whether patients in self-funded ERISA plans are entitled to independent review. This elevates form over substance, but it is an inevitable product of the split federal-state jurisdiction over insurance that ERISA created in the first place.

\section{CONCLUSIONS}

The Moran decision is consistent with ERISA's original design, which kept the business of insurance under state jurisdiction and placed ERISA plans themselves under federal law even though they use insurance to provide employee benefits. In Moran, the Supreme Court makes clear that it is no longer prudent to assume that HMOs are exempt from state insurance regulation merely because they serve ERISA plans. In particular, HMOs that serve fully insured ERISA plans must comply with state laws requiring independent review of determinations of medical necessity. HMOs that administer self-funded ERISA plans may also have to comply if they make binding decisions about coverage. However, deciding what counts as insurance regulation that is enforceable against HMOs that serve ERISA plans remains a highly technical exercise.

The Supreme Court's ruling in Moran may encourage increased state regulation of HMOs and reduce pressure on Congress to enact federal legislation providing national standards for independent external review, liability, and other aspects of managed care. This raises the policy question of whether managed-care practices are best regulated at the state or federal level. Only federal legislation can require nationally uniform rules for all patients and physicians.

I am indebted to Carrie Buchanan for research assistance in cataloguing and analyzing state laws regarding independent external review.

\section{REFERENCES}

1. S. 1052 (passed June 29, 2001), H.R. 2563 (passed August 2, 2001), 107th Cong., lst Sess.

2. Employee Retirement Income Security Act of 1974, 88 Stat. 829 (as amended and codified at 29 U.S.C. $\$ \$ 1001$ et seq.).

3. Rush Prudential HMO, Inc. v. Moran, 122 S. Ct. 2151 (2002).

4. Illinois Health Maintenance Organization Act, 215 Ill. Comp. Stat. Ann. ch. 125, \$ 4-10.

5. Stempel JW. Law of insurance contract disputes. 2nd ed. Gaithersburg, Md.: Aspen Law \& Business, 1999.

6. Couch G, Anderson GR, Rhodes M. Cyclopedia of insurance law [and supplements]. 3rd ed. Deerfield, Ill.: Clark Boardman Callaghan, 1995.

7. Employee Retirement Income Security Act, $\$ 2$, (codified at 29 U.S.C. $\$ 1001)$.
8. Mariner WK. Problems with employer-provided health insurance - the Employee Retirement Income Security Act and health care reform. N Engl J Med 1992;327:1682-5.

9. Employee Retirement Income Security Act, $\$ 514$ (codified at 29 U.S.C. $\$ 1144(\mathrm{a}))$.

10. Pilot Life Ins. Co. v. Dedeaux, 481 U.S. 41 (1987).

11. Employee Retirement Income Security Act, $\$ 3$ (codified at 29 U.S.C. $\$ 1002)$.

12. Fronstin P. Sources of health insurance and characteristics of the uninsured: analysis of the March 2001 Current Population Survey. EBRI

Issue Brief no. 240. Washington, D.C.: Employee Benefits Research Institute, December 2001.

13. Copeland C. Nonelderly individuals with employment-based and individually purchased health care coverage. In: EBRI Notes. Vol. 21. No. 1. Washington, D.C.: Employee Benefits Research Institute, May 2000:3-7.

14. Mariner WK. State regulation of managed care and the Employee Retirement Income Security Act. N Engl J Med 1996;335:1986-90.

15. Chirba-Martin MA, Brennan TA. The critical role of ERISA in state health reform. Health Aff (Millwood) 1994;13(2):142-56.

16. Moran v. Rush Prudential HMO, Inc., 230 F.3d 959 (7th Cir. 2000) 17. Employee Retirement Security Act $\$ 514(\mathrm{~b})(2)$, codified at 29 U.S.C. $\$ 1144(\mathrm{~b})(2)$.

18. McCarran-Ferguson Act, 15 U.S.C. $\$ 1012$ (b)

19. Group Life \& Health Ins. Co. v. Royal Drug Co., 440 U.S. 205 (1979).

20. Metropolitan Life Insurance Co. v. Massachusetts, 471 U.S. 724

(1985).

21. FMC Corporation v. Holliday, 498 U.S. 52 (1990).

22. UNUM Life Ins. Co. of America v. Ward, 526 U.S. 358 (1999).

23. Union Labor Life Ins. Co. v. Pireno, 458 U.S. 119 (1982).

24. Employee Retirement Income Security Act, $\$ 502(a)(1)(B)$ (codified at 29 U.S.C. $\$ 1132(\mathrm{a})(\mathrm{l})(\mathrm{B}))$.

25. Mariner WK. Liability for managed care decisions: the Employee Retirement Income Security Act (ERISA) and the uneven playing field. Am J Public Health 1996;86:863-9.

26. Massachusetts Mut. Life Ins. Co. v. Russell, 473 U.S. 134 (1985).

27. Pilot Life Ins. Co. v. Dedeaux, 481 U.S. 41 (1987).

28. Metropolitan Life Insurance Co. v. Taylor, 481 U.S. 58 (1987)

29. Ingersoll-Rand Co. v. McClendon, 498 U.S. 133 (1990).

30. Jordan KA. Coverage denials in ERISA plans: assessing the federal legislative solution. Mo L Rev 2000;65:405-72.

31. Kinney ED. Tapping and resolving consumer concerns about health care. Am J Law Med 2000;26:335-99.

32. Dallek G, Pollitz K. External review of health plan decisions: an update. Washington, D.C.: Kaiser Family Foundation, May 2000 (Publication no. 3020.) (Also available at http://www.kff.org/content/2000/3020/.) 33. Department of Labor. 29 CFR part 2560: Employee Retirement Income Security Act of 1974: rules and regulations for administration and enforcement: claims procedure: final rule. Fed Regist 2000;65(225): 70245-71.

34. Pegram v. Herdrich, 530 U.S. 211 (2000).

35. New York State Conference of Blue Cross \& Blue Shield Plans v. Travelers Ins. Co., 514 U.S. 645 (1995).

36. DeBuono v. NYSA-ILSA Medical and Clinical Services Fund, 520 U.S. 806 (1997)

37. Butler P. Key characteristics of state managed care organization liability laws: current status and experience. Menlo Park, Calif.: Kaiser Family

Foundation, August 2001. (Also available at http://www.kff.org/content/ 2001/3155/MCOReport.pdf.)

38. Dukes v. U.S. Healthcare, 57 F.3d 350 (3d Cir.), cert. denied, 516 U.S. 1009 (1995)

39. Mariner WK. What recourse? - Liability for managed-care decisions and the Employee Retirement Income Security Act. N Engl J Med 2000; 343:592-6.

40. Idem. Slouching toward managed care liability: reflections on doctrinal boundaries, paradigm shifts, and incremental reform. J Law Med Ethics 2001;29:253-77.

41. Corporate Health Ins., Inc. v. Texas Dept. of Ins., 215 F.3d 526 (5th Cir. 2000).

42. Montemayor v. Corporate Health Ins., 122 S. Ct. 2617 (June 24, 2002). 43. Kaiser Family Foundation/Harvard School of Public Health. Update on Americans' views on the consumer protections debate. Washington, D.C.: Henry J. Kaiser Family Foundation, 1999. (Publication no. 1502.) 44. Rubin-Schneiderman v. Merit Behavioral Care Corp., 163 F. Supp. 2d 227 (S.D.N.Y. 2001).

Copyright @ 2002 Massachusetts Medical Society.

2182 - N Engl J Med, Vol. 347, No. 26 • December 26, $2002 \cdot$ www.nejm.org 